5) Bell a my. Radcl. Obs. 1874 pag. 240.

\begin{tabular}{|c|c|c|c|c|c|c|}
\hline \multicolumn{4}{|c|}{ Zeitdauer } & \multicolumn{2}{|r|}{ Opposition } & \multirow{2}{*}{$\begin{array}{l}\text { Beob. berücksichtigt } \\
\text { März 24-April I } 6\end{array}$} \\
\hline $\begin{array}{r}1874 \\
875\end{array}$ & $\begin{array}{l}\text { März } \\
\text { Anril }\end{array}$ & & & I 2 & $\begin{array}{l}\text { März I } 7 \\
\text { April } 6\end{array}$ & \\
\hline & 874 & März & 24 & & $=27 " 05$ & $B=3 s^{\prime \prime} 80$ \\
\hline & & & 25 & & 37.33 & $\begin{array}{l}34.79 \\
34.76\end{array}$ \\
\hline & & & 31 & & 37.88 & 34.92 \\
\hline & & April & & & $3^{6.53}$ & 34.44 \\
\hline & & & Io & & 37.45 & 35.55 \\
\hline & & & I 6 & & 38.20 & \\
\hline & & & 20 & & 37.19 & 35.21 \\
\hline & 1875 & April & 19 & & 37.03 & $34.5^{8}$ \\
\hline & & & 20 & & $3^{6.98}$ & $35.3^{\circ}$ \\
\hline & & & 28 & & $3^{6.9} \mathrm{I}$ & 34.67 \\
\hline & & & $3^{\circ}$ & & 37.19 & 34.84 \\
\hline & & Mai & I 2 & & 36.84 & 34.67 \\
\hline & & & I 4 & & 36.92 & 34.82 \\
\hline & & & & & 37.19 & 35.02 \\
\hline
\end{tabular}

Göttingen 1896 Juni 15 .
6) Schur. S. oben pag. 227

$$
\text { Resultat: } A=37.42 \quad B=35 \text { "10 }
$$

Damit hat man nun folgende Uebersicht über die an grösseren Heliometern ausgeführten Messungen des Jupiterdurchmessers in der Nähe der Opposition:

$\begin{array}{lcccc} & A & B & \text { I: } \alpha & \text { Gew. } \\ \text { Bessel } & 37.66 & 35.24 & 15.6 & 2 \\ \text { Johnson } & 37.31 & 35.11 & 16.9 & \text { I } \\ \text { Winnecke } & 37.39 & 35.20 & 17.1 & 2 \\ \text { Main } & 37.14 & 34.94 & 16.9 & \text { I } \\ \text { Bellamy } & 37.19 & 35.02 & 17.1 & \text { I } \\ \text { Schur } & 37.42 & 35.10 & 16.2 & 2 \\ \text { Mittel m. Gew. } 37.40 & 35.13 & 16.52 & \end{array}$

Die Gewichte sind nach der Zahl der Beobachtungen und der inneren Uebereinstimmung geschätzt.

\title{
Errors of Graduation of the Repsold Meridian Circle of the Lick Observatory.
}

\author{
By $R$. H. Tucker.
}

The following set of graduation errors has been determined by means of simultaneous readings of both circles. The instrument is especially adapted to this method, one circle being quickly and conveniently set to any desired reading, with respect to the other.

The process followed, has been: first, the measurement of the $45^{\circ}$ divisions. Complete series were taken in both positions of the instrument, fixed circle East, and fixed circle West, for the purpose of strengthening this measurement. The determination of the $15^{\circ}$ arcs follows, depending upon measurements from $0^{\circ}$ and $45^{\circ}$. The $3^{\circ}$ arcs are next determined, each measured from two of the I $5^{\circ}$ divisions.

These later series give new determinations of the $45^{\circ}$ divisions; and the $3^{\circ}$ series furnish, also, another determination of the $15^{\circ}$ divisions. These values are then introduced, with their appropriate weights, and a recomputation of the $3^{\circ}$ arcs is carried out. Up to this point, the $3^{\circ}$ divisions of both circles have been measured, the determination for each circle being independent of the actual errors of the other.

The measurement of the intermediate $I^{\circ}$ divisions of the fixed circle, $A$, has been made, by comparison of one of the $3^{\circ}$ arcs of the movable circle, $B$, with $A$, through $90^{\circ}$ of the latter; changing the position of $B$, one degree, for each series. The ninety series, thus observed, give the errors of the four $1^{\circ}$ divisions of $B$, with considerable precision, and independent of the errors of $A$.

The series of $\mathrm{I}^{\circ}$ arcs furnish other determinations of each $3^{\circ}$ division of $A$, measured from the two nearest $3^{\circ}$ divisions. These have been included, with their proper weight, in the final values. This process, while changing the value first obtained but slightly, in general, has the technical advantage of the employment of all available material for each correction. It renders somewhat more conspicuous the periodic character of the errors.

The agreement of the various measures has been satisfactory; and they afford the means of computing the probable errors of the final values. This has been done, also, by comparison of the results of individual series; and the probable errors are in accord with the quantities to be expected, from the combination of the accidental errors of observation, with the probable errors of the measurement of the graduations, used as standard. For the final corrections, the probable error increases from \pm 0 ".० I for the divisions best determined, to $\pm 0 . " \circ 35$ for the corrections to the intermediate $I^{\circ}$ arcs.

The circles are two feet in diameter, and are graduated, alike, to every $2^{\prime}$. The microscopes are 26 inches focal length, and have a power of 35 diameters. The threads are about $25^{\prime \prime}$ apart.

All necessary precautions and checks have been used throughout the work. The series have never more than barely exceeded an hour, each, in length; and have always been observed forward and back, in order to control changes in the position of the microscopes, and to eliminate those of a progressive character. Each determination rests upon series observed in opposite quadrants, for the elimination of circle flexure. This has however been measured, and the corrections are represented by the quantities:

Circle $A+0.08 \sin \left(R-35^{\circ}\right)+0.04 \cos \left(R-35^{\circ}\right)$

Circle $B+0.02 \sin \left(R-315^{\circ}\right)+0.05 \cos \left(R-315^{\circ}\right)$

where $R$ is the reading of either circle, at the lower left hand microscope. The fixed circle reads $3^{1} 5^{\circ}$, when the telescope points to the zenith. 
The table following gives the corrections due to graduation, for the mean of four divisions. The measurement has been made from $0^{\circ}$ as a base. The mean of the corrections may then be adopted, as the most probable value of the error of $0^{\circ}$; and the column of residuals will represent the actual graduation corrections. The average residual for circle $A$ is \pm 0.18 ; and the probable error of a circle reading upon four divisions, due to graduation, would be \pm 0.15 .

For circle $B$ the average residual is \pm 0.15 .

\begin{tabular}{|c|c|c|c|c|c|c|c|c|c|c|c|}
\hline \multicolumn{9}{|c|}{ Circle $A$} & \multicolumn{3}{|c|}{ Circle $B$} \\
\hline $0^{\circ}$ & 0."00 & $\begin{array}{c}v \\
+0.18\end{array}$ & $30^{\circ}$ & - o." 18 & $\begin{array}{c}v \\
0.00\end{array}$ & $60^{\circ}$ & +o". I I & $\begin{array}{c}v \\
+0.29\end{array}$ & $0^{\circ}$ & o."oo & $\begin{array}{c}y \\
+0.10\end{array}$ \\
\hline I & +0.09 & +0.27 & $3^{1}$ & -0.02 & +0.16 & 61 & -0.02 & +0.16 & 3 & +0.19 & +0.29 \\
\hline 2 & -0.15 & +0.03 & $3^{2}$ & -0.24 & -0.06 & 62 & -0.19 & -0.01 & 6 & 0.00 & +0.10 \\
\hline 3 & +0.22 & +0.40 & 33 & $-0.5^{8}$ & -0.40 & 63 & -0.07 & +0.11 & 9 & +0.04 & +0.14 \\
\hline 4 & -0.16 & +0.02 & 34 & -0.64 & -0.46 & 64 & -0.16 & +0.02 & 12 & +0.14 & +0.24 \\
\hline 5 & -0.37 & -0.19 & 35 & -0.86 & -0.68 & 65 & -0.18 & 0.00 & 15 & -0.29 & -o. I 9 \\
\hline 6 & $-0.3^{\circ}$ & -0.12 & 36 & -0.70 & $-0.5^{2}$ & 66 & -0.12 & +0.06 & 18 & -0.06 & +0.04 \\
\hline 7 & -0.26 & -0.08 & 37 & -0.44 & -0.26 & 67 & -0.40 & -0.22 & $2 \mathrm{I}$ & +0.13 & +0.23 \\
\hline 8 & +0.04 & +0.22 & $3^{8}$ & -0.26 & -0.08 & 68 & -0.25 & -0.07 & 24 & -0.05 & +0.05 \\
\hline \multirow[t]{2}{*}{9} & -0.06 & +0.12 & 39 & -0.21 & -0.03 & 69 & -0.33 & -0.15 & 27 & +0.27 & +0.37 \\
\hline & & & & & & & & & 30 & -0.17 & -0.07 \\
\hline 10 & -0.12 & +0.06 & 40 & -0.41 & -0.23 & 70 & -0.42 & -0.24 & 33 & -0.34 & -0.24 \\
\hline 11 & -0.08 & +0.10 & 41 & $-0.3^{I}$ & -0.13 & 71 & -0.26 & -0.08 & 36 & -0.44 & -0.34 \\
\hline I 2 & -0.23 & -0.05 & 42 & -0.39 & -0.21 & 72 & -0.40 & -0.22 & 39 & -0.37 & -0.27 \\
\hline 13 & $-0.3^{6}$ & -0.18 & 43 & -0.46 & -0.28 & 73 & -0.14 & +0.04 & 42 & -0.39 & -0.29 \\
\hline 14 & -0.46 & -0.28 & 44 & -0.46 & -0.28 & 74 & +0.10 & +0.28 & 45 & -0.07 & +0.03 \\
\hline 15 & -0.33 & -0.15 & 45 & $-0.5^{2}$ & -0.34 & 75 & +0.09 & +0.27 & 48 & -0.08 & +0.02 \\
\hline I 6 & $-0.4^{8}$ & -0.30 & 46 & -0.22 & -0.04 & 76 & +0.05 & +0.23 & $5^{\mathrm{I}}$ & -0.29 & -0.19 \\
\hline 17 & $-0.5^{\circ}$ & $-0.3^{2}$ & 47 & +0.08 & +0.26 & 77 & +0.28 & +0.46 & 54 & -0.28 & -0.18 \\
\hline 18 & $-0.4 x$ & -0.23 & 48 & +0.10 & +0.28 & 78 & +0.12 & +0.30 & 57 & -0.02 & +0.08 \\
\hline \multirow[t]{2}{*}{19} & -0.47 & -0.29 & 49 & -0.04 & +0.14 & 79 & +0.12 & +0.30 & 60 & +0.05 & +0.15 \\
\hline & & & & & & & & & 63 & -0.17 & -0.07 \\
\hline 20 & -0.19 & -0.01 & 50 & -0.19 & -0.01 & 80 & -008 & +0.10 & 66 & -0.22 & -0.12 \\
\hline 21 & -0.17 & +0.01 & 51 & -0.22 & -0.04 & $8 I$ & -0.02 & +0.16 & 69 & -0.12 & -0.02 \\
\hline 22 & -0.33 & -0.15 & $5^{2}$ & $-0.3^{8}$ & -0.20 & 82 & +0.14 & +0.32 & 72 & -0.24 & -0.14 \\
\hline 23 & -0.19 & -0.01 & 53 & -0.18 & 0.00 & 83 & +0.25 & +0.43 & 75 & -0.08 & +0.02 \\
\hline 24 & -0.14 & +0.04 & 54 & -0.16 & +0.02 & 84 & +0.12 & +0.30 & 78 & +0.13 & +0.23 \\
\hline 25 & -0.23 & -0.05 & 55 & $-0.1 \mathrm{I}$ & +0.07 & 85 & 0.00 & +0.18 & 81 & -0.02 & +0.08 \\
\hline 26 & -0.46 & -0.28 & $5^{6}$ & +0.06 & +0.24 & 86 & +0.07 & +0.25 & 84 & -0.13 & -0.03 \\
\hline 27 & -0.22 & -0.04 & 57 & +0.22 & +0.40 & 87 & -0.06 & +0.12 & 87 & -0.03 & +0.07 \\
\hline 28 & -0.11 & +0.07 & $5^{8}$ & +0.20 & $+0.3^{8}$ & 88 & -0.22 & -0.04 & 88 & -0.26 & -0.16 \\
\hline 29 & -0.19 & -0.01 & 59 & +0.02 & +0.20 & 89 & +0.02 & +0.20 & 89 & -0.18 & -0.08 \\
\hline
\end{tabular}

This undertaking has been accomplished with the volunteer assistance of Professor $R$. G. Aitken, for the simultaneous reading of the circles. No single series has been discarded; but, one series of $45^{\circ}$ arcs, and three

series of $\mathrm{I}^{\circ}$ arcs have been repeated, upon indications of larger accidental errors than usual, and the results combined with those of the original series. It has required, for the complete determination, 29000 microscope readings.

Lick Observatory, 1896 May 6.

$$
\text { R. H. Tucker. }
$$

\section{Effemeride del pianeta (354)}

per la quarta apparizione.

La seguente effemeride, valevole per $12^{\mathrm{b}} \mathrm{t} . \mathrm{m}$. di Berlino, ha per base il sistema di elementi da me pubblicato nel No. 3292 delle Astr. Nachr. (dove peró in luogo di $\pi=145^{\circ} 2 I^{\circ} 4^{\prime \prime} 84$ si deve leggere $\infty=5^{\circ} 2 I^{\circ} 4.84$ ) trasportato all' epoca della prossima opposizione in longitudine (5.5 Novembre 1896) con riguardo alle perturbazioni di Giove e Saturno.
Farmi conveniente di avvertire in questa occasione che la correzione di oltre $2 \mathrm{I}^{\mathrm{s}}$ in AR. risultante dalle osservazioni del 1895 (v. Astr. Nachr. 3304) per l' effemeride calcolata sullo stesso sistema è quasi interamente dovuta ad errore commesso nel trasporto del sistema all' epoca della terza apparizione. 